\title{
Water Quality and Phytoplankton Diversity in Büyükçekmece Watershed, Turkey
}

\author{
Yasemin Gulecal*, Mustafa Temel \\ Department of Freshwater Biology, University of Istanbul, Istanbul, Turkey \\ Email: *ygulecal@istanbul.edu.tr
}

Received November 28, 2013; revised December 26, 2013; accepted January 18, 2014

Copyright (C) 2014 Yasemin Gulecal, Mustafa Temel. This is an open access article distributed under the Creative Commons Attribution License, which permits unrestricted use, distribution, and reproduction in any medium, provided the original work is properly cited. In accordance of the Creative Commons Attribution License all Copyrights (C) 2014 are reserved for SCIRP and the owner of the intellectual property Yasemin Gulecal, Mustafa Temel. All Copyright @ 2014 are guarded by law and by SCIRP as a guardian.

\begin{abstract}
Seasonal changes in the diversity of phytoplankton and its relationships to the water quality in Büyükçekmece Watershed in Istanbul, Turkey were studied in this study during one-year period, from January 2009 to December 2009. Physico-chemical parameters, main criteria of water quality, were observed. Having identified species from 6 divisions, including Bacillariophyta, Chlorophyta, Cyanophyta, Euglenophyta, Dinophyta and Cryptophyta within the phytoplankton of Büyükçekmece Lake, and that of the named influent streams, Bacillariophyta among these divisions has been specified as the richest group in species variety. Among the streams having gone under sampling, Tahtaköprü Stream has displayed the species variety (48), and respectively Karasu (45), Hamza Stream (32), Beylikçayırı Stream (21) and Ahlat Stream (7) have come thereafter. Within the phytoplankton of Büyükçekmece Lake, 66 species have been identified. It was determined that the water qualities of Büyükçekmece Lake and related streams were varies I, II and III.
\end{abstract}

\section{KEYWORDS}

\section{Büyükçekmece Watershed; Diversity; Water Quality; Phytoplankton}

\section{Introduction}

Today 1.2 billion people (20\% of the world population) already have no secure access to clean drinking water and 2.4 billion people do not dispose of access to sanitary installations. Millions of children die every year due to polluted water [1]. In this respect, researches in water quality are important to increase the awareness of more efficient use of water and water resources that are the most precious treasure of humankind. Annual available water per capita is $3690 \mathrm{~m}^{3}$ in Turkey whereas world average is $7600 \mathrm{~m}^{3}$. Even though Turkey is not one of the water-poor countries, there is still shortage of water. Also, to minimize the adverse impact of climate change, existing water resources should be used wisely [2]. Hence, sources supplying freshwater to mega cities such as Istanbul must be closely monitored and biologically investigated to ensure the quality.

The phytoplankton in a freshwater source is an impor-

"Corresponding author. tant biological indicator of the water quality. Phytoplankton studies and monitoring are useful for control of the physico-chemical and biological conditions of the water in any irrigation project [3]. Therefore, certain groups of phytoplankton, especially blue-green algae, can degrade recreational value of surface water, particularly thick surface scum, which reduces the use of amenities for contact sports, or large concentrations, which cause deoxygenation of the water leading to fish death [4]. Over the last few decades, there has been much interest in the processes influencing the development of phytoplankton communities, primarily in relation to water quality [5-7].

The algae co-occur even though each species has a specific niche based on its physiological requirements and the constraints of the environment. These are many detailed descriptions of phytoplankton succession being correlated with changes in environmental parameters particularly temperature, light, nutrients availability and mortality factors such as grazing and parasitism. Because 
the variation of phytoplankton succession is strongly linked to meteorological and water stratification mixing processes, patterns in temperate ecosystems differ considerably from those of tropical waters [8]. The dynamics of phytoplankton are a function of some environmental processes that affect species diversity. For example, the onset of the spring bloom in dimictic lakes is controlled by the relief of light limitation at a time when nutrient concentrations are high and growth abundance is low [9]. The abundance of algae of different kinds is rather closely associated with restricted seasonal periodicity, differing of course in widely separated geographical locations [10].

The study area Büyükçekmece Watershed has approximately 63,000 ha surface area, and it is the second largest watershed in Istanbul. Annually, 17\% of drinking water of Istanbul is supplied from this watershed. As this area is under risk due to farmland, industrial activities and increase in population, it has to be kept under supervision. Although there are researches on the water quality and phytoplankton of Büyükçekmece Lake [11,12], the phytoplankton and water quality of the streams emptying into to Büyükçekmece Watershed have not been researched yet. In this study, the purpose was to specify the phytoplankton diversity and certain physicochemical parameters of Büyükçekmece Lake and the streams feeding the lake, e.g. Hamza Stream, Ahlat Stream, Karasu Stream, Tahtaköprü Stream, Beylikçayı Stream and elucidate the linkages among phytoplankton community composition and water quality. Furthermore, it is thought that the data obtained from this study will provide information to similar studies and contribute to Turkey's algal flora.

\section{Materials and Methods}

\subsection{Study Site}

Büyükçekmece Watershed is used as drinking water resources, located (41006'89'N, 28055'65'”E) approximately $30 \mathrm{~km}$ to the southwest of Istanbul (Figure 1). The lake's bar was reinforced in 1988 by a dam. The area of the lake is $28.47 \mathrm{~km}^{2}$ and lies in a $620 \mathrm{~km}^{2}$ watershed. Büyükçekmece Lake is $7 \mathrm{~km}$ long and $2 \mathrm{~km}$ wide. The maximum depth is $8.6 \mathrm{~m}$ following deepening works carried out by the Ministry of Environment and Forestry of Turkey. The largest stream feeding the lake is Karasu Stream, which is connected with other streams. Others are Hamza Stream, Ahlat Stream, Tahtaköprü Stream and Beylikçayı Stream.

\subsection{Sampling and Analysis}

Between January and December 2009, this research was conducted on the water samples collected from Büyük-

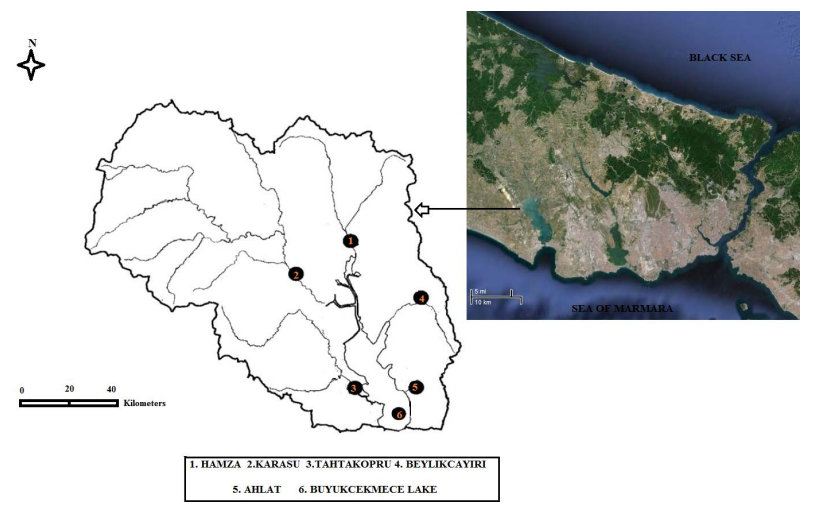

Figure 1. Büyükçekmece Watershed and location of the sampling stations (source: Google Earth).

çekmece Lake and certain streams feeding the lake, on a monthly basis. The samples were collected from the points where the streams join Büyükçekmece Lake and which are close enough to collect samples.

The water samples were collected in Nansen bottles from above the surface and fixed with Lugol's solution. The phytoplankton counts were performed by using an inverted Nikon microscope in a zoom in of 400 according to the method of Lund et al. (1958) [13]. Some of the samples brought into the laboratory were filtered through GF/A glass fiber filter paper by using water jet pump and the algae other than the diatoms in the temporary preparations were identified. The identification of the diatoms was performed on the permanent preparations prepared with Entellan mounting medium after burning and cleaning the cell walls by adding a $1 / 1$ solution of sulfuric acid and nitric acid. In the identification of phytoplankton species, we have benefited from the literatures of Desikachary (1959), Patrick-Reimer (1966,1975), Huber-Pestalozzi (1975), Krammer and Lange-Bertalot (1986), Hustedt (1930, 1985), Prescott (1964), Reynolds et al. (2002), John et al. (2003) and Padisak et al. (2009) [14-23].

The temperature and the $\mathrm{pH}$ were measured in situ at the time of sample collection by using a multiparameter model of YSI 600XL. Chemical parameters were analyzed in accordance with Standars Methods for the Examination of Water and Waste Water [24]. In the samples brought to the laboratory, the amount of dissolved oxygen was determined according to the Winkler method and ammonia was determined according to selective electrode method. The chemical oxygen demand was volumetrically quantified using a reducing agent. Amount of total phosphorus and nitrate were determined by using autoanalyzer (Skalar San System).

\subsection{Data Analysis}

Statistical analyses were performed using the software 
program Primer 6.0 [25]. Diversity of phytoplankton ( $\left.\mathrm{H}^{\prime}\right)$ was calculated according to the Shannon-Wiener index. In order to identify interrelationships among sampling sites, cluster analysis using the Bray-Curtis similarity index [26].

\section{Results and Discussion}

\subsection{Water Quality Parameters}

Büyükçekmece Watershed is very important to Istanbul as it supplies about $17 \%$ of the total annual freshwater need of the city. The field area's some water quality parameters determined in this study are given Table 1. Mean water temperature varied from $12.64^{\circ} \mathrm{C}$ in Beylikçayırı Stream to $16.07^{\circ} \mathrm{C}$ in Büyükçekmece Lake. The dissolved oxygen ranged between 7.85 and 9.25 $\mathrm{mg} / \mathrm{L}$ and $\mathrm{pH}$ values ranged between 7.58 and 7.82. Chemical oxygen demand (COD) was less than 25 $\mathrm{mgl}^{-1}$ at all stations. Ammonium values varied from < 0.05 to 1.14 and the maximum value was recorded in Beylikçayırı Stream. Average of nitrate and total phosphorus values are shown in Table 2.

The classification of the water quality of Büyükçekmece Lake and related streams were evaluated in terms of temperature, $\mathrm{pH}$, oxygen, nitrate, total phosphorus, ammonia and chemical oxygen demand according to Turkish Water Pollution Control Regulation in Table 1 [27]. According to this regulation classifying the water quality with respect to temperature Büyükçekmece Lake provide class I and II, all streams provides class II criteria. It was reported that the oxy- gen concentration in unpolluted waters is generally among $10 \mathrm{mgl}^{-1}$ if it decreases below $5 \mathrm{mgl}^{-1}$ the biological life functions decrease too. It is known that $\mathrm{pH}$ changes between 6 - 9 in unpolluted lake waters [28].

All the stations are included in class I classification quality with respect to $\mathrm{pH}$ and nitrate according to the regulation mentioned above. With respect to dissolved oxygen Büyükçekmece Lake, Tahtalikoy Stream, Karasu Stream provide class I, Ahlat Stream provides class II. The COD amount in Büyükçekmece Lake and related streams is calculated less than $30 \mathrm{mgl}^{-1}$. This value does not exceed the limit value of the mentioned regulation but it stays at the limit value. Considering total phosphorus, according to the regulation that we have mentioned, Büyükçekmece Lake, Tahtalikoy Stream, Karasu Stream are in class II classification, Ahlat and Hamza Stream is in class III and Beylikcayiri Stream IVclassification.

\subsection{Variations of Phytoplankton}

A total of 69 species in the six divisions of phytoplankton were identified from lake and related five streams (Table 3). The richest species group is recorded as $\mathrm{Ba}$ cillariophyta (47 species), followed by Chlorophyta (9 species), Cyanophyta (6 species), Euglenophyta (3 species), Cryptophyta (3 species) and Dinophyta (1 species). Cyclotella ocellata was identified as the dominant algae species in all stations. Bacillariophyta was recorded as dominant divisio in streams during phytoplankton studies in Turkey [29-31].

Table 1. Water quality classification of inland surface waters (Turkish Water Pollution Control Regulation 2004, TWPCR).

\begin{tabular}{ccccc}
\hline Parameter & CLASS I & CLASS II & CLASS III & CLASS IV \\
\hline Temperature $\left({ }^{\circ} \mathrm{C}\right)$ & 25 & 25 & 30 & $>30$ \\
$\mathrm{pH}$ & $6.5-8.5$ & $6.5-8.5$ & $6.0-9.0$ & $>6.0-9.0$ \\
$\mathrm{D} . \mathrm{O} .(\mathrm{mg} / \mathrm{L})$ & 8 & 6 & 3 & $<3$ \\
$\mathrm{COD}(\mathrm{mg} / \mathrm{L})$ & 25 & 0.16 & 70 & $>70$ \\
Total $\mathrm{P}(\mathrm{mg} / \mathrm{L})$ & 0.02 & 10 & 20 & $>0.65$ \\
$\mathrm{NO}_{3}-\mathrm{N}(\mathrm{mg} / \mathrm{L})$ & 5 & $0.2-1$ & $1-2$ & $>20$ \\
$\mathrm{NH}_{4}-\mathrm{N}(\mathrm{mg} / \mathrm{L})$ & $<0.2$ & & $>2$ & \\
\hline
\end{tabular}

Table 2. Mean physical and chemical data of Büyükçekmece Watershed during the study period of January-December 2009.

\begin{tabular}{|c|c|c|c|c|c|c|}
\hline Parameter & Station I & Station II & Station III & Station IV & Station V & Station VI \\
\hline Temperature $\left({ }^{\circ} \mathrm{C}\right)$ & 16.07 & 12.82 & 13.54 & 14.20 & 13.55 & 12.64 \\
\hline $\mathrm{pH}$ & 7.82 & 7.68 & 7.60 & 7.73 & 7.81 & 7.58 \\
\hline D.O. (mg/L) & 9.25 & 9.06 & 8.01 & 7.85 & 8.10 & 8.16 \\
\hline COD (mg/L) & $<25$ & $<25$ & $<25$ & $<25$ & $<25$ & $<25$ \\
\hline Total P (mg/L) & 0.09 & 0.16 & 0.40 & 1.12 & 0.14 & 0.48 \\
\hline $\mathrm{NO}_{3}-\mathrm{N}(\mathrm{mg} / \mathrm{L})$ & 0.85 & 0.64 & 0.72 & 0.62 & 0.83 & 1.43 \\
\hline $\mathrm{NH}_{4}-\mathrm{N}(\mathrm{mg} / \mathrm{L})$ & $<0.05$ & 0.05 & 0.38 & 0.61 & 0.14 & 1.14 \\
\hline
\end{tabular}

(I: Lake water, II: Karasu Stream, III: Hamza Stream, IV:Ahlat Stream, V:Tahtaköprü Stream, VI:Beylikçayırı Stream). 
Table 3. Phytoplankton species recorded in the study area stations from January-December 2009.

\begin{tabular}{|c|c|c|c|c|c|c|}
\hline TAXON & I. & II. & III. & IV. & V. & VI. \\
\hline \multicolumn{7}{|l|}{ BACILLARIOPHYTA } \\
\hline Achnanthes lanceolata (BREB.) GRUN. & + & & & + & + & + \\
\hline Amphora ovalis KÜTZ. & + & + & & & + & + \\
\hline Aulacoseira italica (EHRENB.) SIMONSEN & + & & + & & + & + \\
\hline Asterionella formosa HASSALL & + & & & & + & + \\
\hline Bacillaria paradoxa GMELİN & + & + & + & & & + \\
\hline Caloneis amphisbanea (BORY) CLEVE & + & & & & + & + \\
\hline Cocconeis placentula EHRENB. & + & + & & & + & + \\
\hline C. placentula var. euglypta (NAEGELI) HUST. & + & & + & & + & + \\
\hline Cyclotella meneghiniana KÜTZ. & & & & & & + \\
\hline Cyclotella ocellata PANTOCSEK & + & + & + & + & + & + \\
\hline Cymatopleura elliptica (BREB.)W. SMITH & & & + & & & + \\
\hline C. solea (BREB.)W. SMITH & + & & & & + & + \\
\hline Cymbella affinis KÜTZ. & + & + & & & + & + \\
\hline Cymbella helvetica KÜTZ. & + & & + & & & + \\
\hline Cymbella lanceolata (EHRENB.) V.HEURCK & & + & + & & & + \\
\hline Cymbella tumida GRUN & + & & + & & & + \\
\hline Cymbella ventricosa KÜTZ. & + & & & & + & + \\
\hline Diatoma vulgare BORY & & + & & & + & + \\
\hline Diploneis sp. & + & & & & + & + \\
\hline Fragilaria crotonensis KITTON & & + & & & + & + \\
\hline Gomphonema acuminatum EHRENB. & + & & + & & + & + \\
\hline Gomphonema augur EHRENB. & + & & & & + & + \\
\hline Gomphonema intricatum EHRENB. & & + & & & + & + \\
\hline Gomphonema olivaceum (LYN.) KÜTZ. & & & + & & + & + \\
\hline Gyrosigma acuminatum (KÜTZ.) RABH. & + & & & & + & + \\
\hline Melosira varians C. A. AGARDH & & & & + & & + \\
\hline Meridion circulare AGARDH & & & & & + & + \\
\hline Navicula cryptocephala KÜTZ. & + & & + & & & + \\
\hline Navicula gracilis EHRENB. & + & + & & & + & + \\
\hline Navicula cuspidata KÜTZ. & + & & & & + & + \\
\hline Navicula sp. & + & & + & & + & + \\
\hline Nitzschia acicularis (KÜTZ.) W. SMİTH & & + & & & + & + \\
\hline Nitzschia linearis W. SMİTH & + & & + & & + & + \\
\hline Nitzschia palea (KÜTZ.) W. SMİTH & & + & & & + & + \\
\hline Nitzschia sigma (KÜTZ.) W. SMİTH & + & & & & & + \\
\hline Nitzschia closterium (EHRENB.) W. SMİTH & & & & & & + \\
\hline Nitzschia hungarica GRUN & & & & & + & + \\
\hline Nitzschia sigmoidea (KÜTZ.) W. SMİTH & & + & & & & + \\
\hline Pinnularia sp. & + & & + & & & \\
\hline Pleurosigma sp. & + & & + & & + & + \\
\hline Stauroneis sp. & & & & & + & + \\
\hline Surirella angutsa KÜTZ. & + & & + & & & + \\
\hline Surirella ovalis BREBİSSON & + & + & + & & + & + \\
\hline Synedra acus KÜTZ. & + & & + & & + & + \\
\hline Synedra ulna EHRENB. & + & & + & & + & + \\
\hline Synedra sp. & & & + & & + & + \\
\hline Tabellaria sp. & & + & & & + & \\
\hline
\end{tabular}




\section{TAXON}

\section{CHLOROPHYTA}

Closterium sp.

Cosmarium formosulum HOFFMAN

Gonium sp.

Pandorina morum (O.F. MÜLLER) BORY

Pediastrum duplex MEYEN

Pediastrum simplex MEYEN

Scenedesmus quadricauda (TURB.) BREB.

S. bijuga var.Alternas (REINSCH) BORGE

Spirogyra sp.

\section{CRYPTOPHYTA}

Cryptomonas erosa EHRENB.

Cryptomonas ovata EHRENB.

Plagioselmis nannoplanctica (SKUJA) NOVA.

CYANOPHYTA

Anabaena affinis LEMMERMANN

A.spiroides KLEBAHN

Anabaenopsis sp.

Merismopedia glauca (EHRENB.) NAEGELI

Oscillatoria princeps VAUCHER

Spirulina major KÜTZ.

\section{DINOPHYTA}

Peridinium sp.

EUGLENOPHYTA

Euglena acus EHRENB.

E. ehrenbergii KLEBS

Phacus orbicularis HUEBNER
I.

II.

III.

IV.

V.

VI.

$\begin{array}{lll}+ & + \\ + & + \\ + & + \\ + & + \\ + & +\end{array}$

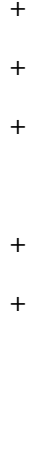

$+$

$+$
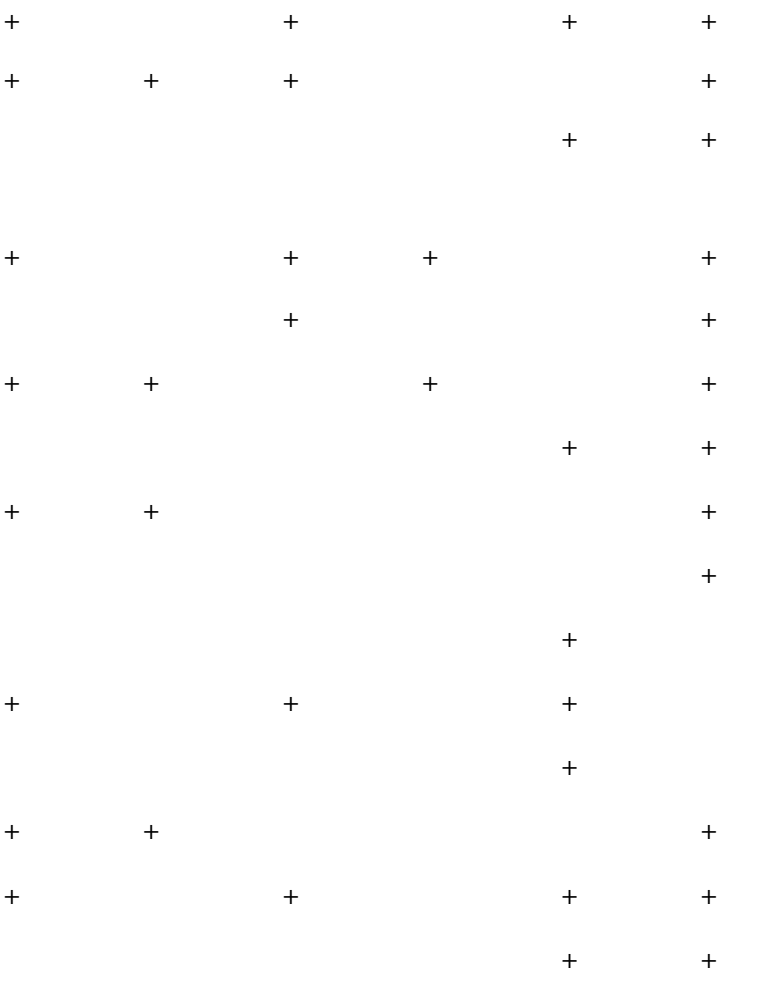

(I: Karasu Stream, II: Beylikçayırı Stream, III: Hamza Stream, IV: Ahlat Stream, V: Tahtaköprü Stream, VI: Büyükçekmece Lake, +: exist).

Increment with water temperature and nutrients was observed in summer, correspondingly phytoplankton population was increased at all stations. During the research, maximum algae density was recorded in July 2009 as $200 \mathrm{ind} / \mathrm{cm}^{3}$ in Ahlat Stream which nitrate was calculated high and the dominant species was Scenedesmus quadricauda composing $50 \%$ of phytoplankton.The maximum algae density in Hamza Stream was recorded in Agust 2009 (346 ind $\left./ \mathrm{cm}^{3}\right)$, nitrate and the total phosphorus were also observed at maximum values and do- minant species Cyclotella ocellata composing $73.6 \%$ of phytoplankton. The maximum algae density in Beylikcayiri Stream was recorded in July 2009 (896 ind $\left./ \mathrm{cm}^{3}\right)$ which nitrate and the total phosphorus were also calculated at increases values and dominant species Navicula gracilis composing $61.27 \%$ of phytoplankton.Tahtakopru Stream and Karasu Stream were recorded maximum density of phytoplankton in July 2009, phosphate was also calculated at maximum value and dominant species Cryoptomonas ovate composing $51.44 \%$ of phytoplank- 
ton and Cyclotella ocellata composing $75 \%$ of phytoplankton, respectively. The maximum algae density in Buyukcekmece Lake was recorded in July 2009 as $14,665 \mathrm{ind} / \mathrm{cm}^{3}$ which nitrate increases in the same month, dominant specy Scenedesmus quadricauda composing $71.3 \%$ of phytoplankton (Figure 2).

As a result of the Shanon-Wiener, the diversity index was the highest in Büyükçekmece Lake. It was followed by Tahtakopru Stream, Karasu Stream, Hamza Stream, Ahlat Stream and Beylikcayiri Stream (Figure 3). The analysis of the species diversity is used to explain the structure of community. It is known that the highest diversity of communities are composed of a lot of species [32].

Considering Bray-Curtis similarity analysis results two major groups were identified at 66\% similarity level. Karasu and Tahtakopru Stream stations 90.77\%, Beylikcayiri and Hamza Stream stations 79.24\% showed similarities (Figure 4).

\section{Conclusion}

In conclusion, diversity and abundance of phytoplankton of Büyükçekmece Watershed are related with parameters of water quality. Low phytoplankton diversity and high value of chemical parameters were determined in Beylikcayiri Stream, whereas in Büyükçekmece Lake high phytoplankton diversity and low value of chemical parameters were observed. As is known, one of the significant factors that affect the algae development in aquatic

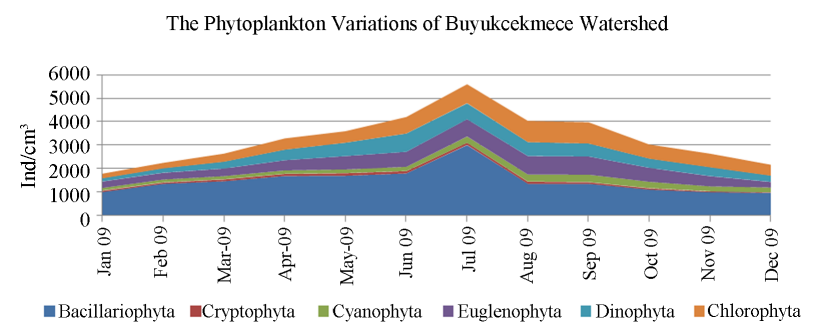

Figure 2. Seasonal variations of abundance of phytoplankton in Buyukcekmece Watershed.

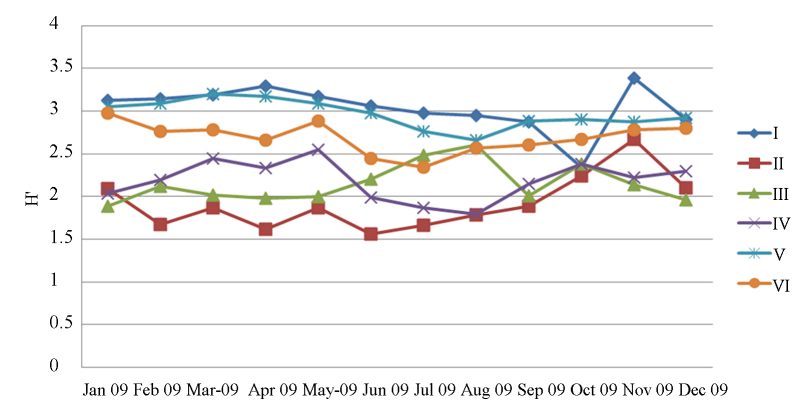

Figure 3. Phytoplankton species Shanon-Wiener diversity index during the study period in Buyukcekmece Watershed. (I: Büyükçekmece Lake, II: Beylikçayırı Stream, III: Hamza Stream, IV: Ahlat Stream, V: Tahtaköprü Stream; VI: Karasu Stream).
Buyukcekmece Watershed

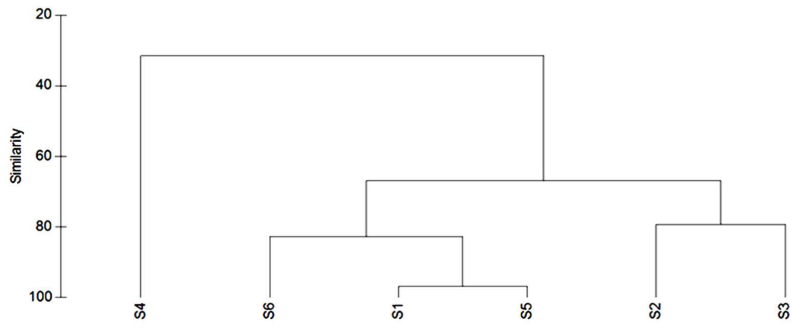

Figure 4. Dendrogram for clustering of samplings during the study period in Büyükçekmece Watershed based on Bray-Curtis similarities. (S1: Karasu Stream, S2: Beylikcayiri Stream, S3: Hamza Stream, S4: Ahlat Stream, S5: Tahtakopru Stream, S6:Buyukcekmece Lake).

environments is nutrients. It is known that there is a positive correlation between the amount of nitrate and total phosphorus in water and the development of phytoplankton $[33,34]$. Similarly, the maximum algae density in Büyükçekmece Watershed was recorded in summer months, which was also calculated at maximum values in nitrate and the total phosphorus. Büyükçekmece Lake is oligotrophic lake [11] and the related streams influencing it are not under the risk according to our data. Especially the species diversity index value which is above the risk limit as more than 2.5 proves it. However, being in urban area, Buyukcekmece Watershed is under threat of pollutants. Thus, particularly feeding streams' phytoplankton levels effecting water quality must be monitored periodically. Findings of this research will be the basis of future studies.

\section{REFERENCES}

[1] A. Lozan, H. Gralb, P. Hupfer, L. Menzel and Ch.-D. Schönwiese, “Global Change: Enough Water for All?” Wissenschaftlic Auswertungen/GEO Hamburg, 2007.

[2] S. Zekai, "Iklim Degisikligi Tatlisu Kaynaklari ve Turkiye,” Su Vakfi Yayinlari, Istanbul, 2009.

[3] L. Naselli-Flores, "Phytoplankton Assemblages in TwentyOne Sicilian Reservoirs: Relationships between Species Composition and Environmental Factors," Hydrobiologia, Vol. 424, No. 1-3, 2000, pp. 1-11. http://dx.doi.org/10.1023/A:1003907124528

[4] B. A. Whitton and M. Patts, "The Ecology of Cyanobacteria,” Kluwer Academic, Dordrecht, 2000.

[5] N. Akbay, N. Anul, S. Yerti, S. Soyupak and C. Yurteri, "Seasonal Distribution of Large Phytoplankton in Keban Dam Reservoir,” Plankton Research, Vol. 21, No. 4, 1999, pp. 771-787. http://dx.doi.org/10.1093/plankt/21.4.771

[6] Y. Peerapornpisal, W. Sonthichai, T. Somdee, P. Mulsin and E. Rott, "Water Quality and Phytoplanktonin the Mae Kuang Udomtara Reservoir, Chiang Mai, Thailand," Journal of Science Faculty of Chiang, Vol. 26, No. 1, 1999, pp. 25-43.

[7] J. A. Elliott, A. E. Irish and C. S. Reynolds, "Predicting 
the Spatial Dominance of Phytoplankton in Light Limited and Incompletely Mixed Eutrophic Water Column Using the Protech Model,” Freshwater Biology, Vol. 47, No. 3, 2002, pp. 433-440.

http://dx.doi.org/10.1046/j.1365-2427.2002.00813.x

[8] R. G. Wetzel, “Limnology,” 3rd Edition, Academic Press, California, 2001.

[9] D. Roelke and Y. Buyukates, "Dynamics Phytoplankton Succession Coupled to Species Diversity as a System Level Tool for Study of Microcystis Population Dynamics in Eutrophic Lakes," Limnology and Oceanography, Vol. 47, No. 4, 2002, pp. 1109-1118. http://dx.doi.org/10.4319/lo.2002.47.4.1109

[10] G. M. Smith, "Manual of Phycology," The Ronald Press Company, New York, 1951.

[11] M. Temel, "The Phytoplankton of Lake Buyukcekmece, Istanbul, Turkey,” Pakistan Journal of Botany, Vol. 34, No. 1, 2002, pp. 81-91.

[12] T. G. Guyer and G. E. Ilhan, "Assessment of Pollution Profile in Buyukcekmece Watershed, Turkey,” Environmental Monitoring and Assessment, Vol. 173, No. 1-4, 2010, pp. 211-220. http://dx.doi.org/10.1007/s10661-010-1382-y

[13] J. W. G. Lund, C. Kipling and E. D. Le Cren, "The Inverted Microscope Method of Estimating Algal Numbers and the Statistical Basis of Estimations by Counting," Hydrobiologia, Vol. 11, No. 2, 1958, pp. 143-170. http://dx.doi.org/10.1007/BF00007865

[14] T. V. Desikachary, “Cyanophyta,” Botany Department, Univercity of Madras, New York, 1959.

[15] R. Patrick and C. W. Reimer, "The Diatoms of the United States, Vol. 1,” The Academy of Natural Sciences of Philadelphia, Philadelphia, 1966.

[16] R. Patrick and C. W. Reimer, "The Diatoms of the United States, Vol. 2, part 1,” The Academy of Natural Sciences of Philadelphia, Philadelphia, 1975.

[17] G. Huber-Pestalozzi, "Das Phytoplankton des Süsswassers,” Teil 2 Diatomeen, Band XVI, Stutgard, 1975.

[18] K. Krammer and H. Lange-Bertalot, "Bacillariophyceae," 3.teil. Centrales, Band 2/3, Gustav Fisher Verlag, Stutgard, 1986.

[19] F. Hustedt, "The Pennate Diatoms," Koeltz Scientific Books Koeningstein, 1985.

[20] G. W. Prescott, “The Freshwater Algae,” W. M. C. Brown Company, Dubuque, 1964.

[21] C. S. Reynolds, V. Huszar, C. Kruk, L. Naselli-Flores and
S. Melo, "Towards a Functional Classification of the Freshwater Phytoplankton," Journal of Plankton Research, Vol. 24, No. 5, 2002, pp. 417-428. http://dx.doi.org/10.1093/plankt/24.5.417

[22] D. M. John, B. A. Whitton and A. J. Brook, "The Freshwater Algal Flora of the British Isles,” The Natural History Museum and The British Phycological Society, Cambridge University Press, 2003, 702 p.

[23] J. Padisak, L. O. Crossetti and L. Naselli-Flores, "Use and Misuse in the Application of the Phytoplankton Functional Classification: A Critical Review with Updates," $\mathrm{Hy}$ drobiologia, Vol. 621, No. 1-19, 2009.

[24] APHA, "Standard Methods for the Examination of Water," 21st Edition, American Public Health Association, Washington, 2005.

[25] K. R. Clarke and R. N. Gorley, "PRIMER v6: User Manual/Tutorial,” PRIMER-E, Plymouth, 2006.

[26] K. R. Clarke and R. M. Warwick, "Change in Marine Communities: An Approach to Statistical Analysis and Interpretation,” Natural Environment Research Council, Plymouth Marine Laboratory, Plymouth, 1994.

[27] TWPCR, “Official Gazette 25687,” Turkish Water Pollution Control Regulation, 2004.

[28] B. Moss, "The Influence of Environmental Factors on the Distribution of Freshwater Algae: An Experimental Study: II. The Role of $\mathrm{pH}$ and the Carbon Dioxide-Bicarbonate System,” Journal of Ecology, Vol. 61, No. 1, 1973, pp. 157-160. http://dx.doi.org/10.2307/2258925

[29] Ö. O. Ertan and A. Morkoyunlu, "The Algae Flora of Aksu Stream (Isparta-Turkey),” Turkish Journal of Botany, Vol. 22, No. 2, 1998, pp. 239-255.

[30] E. N. Soylu and A. Gonulol, "Phytoplankton and Seasonal Variations of the River Yeşilırmak, Amasya, Turkey," Turkish Journal of Fisheries and Aquatic Sciences, Vol. 3, 2003, pp. 17-24.

[31] M. Temel, “A Study on Prokaryota (Cyanobacteria, Cyanoprokaryota) and Eukaryota Algae in the Riva (Durusu) Stream, Istanbul, Turkey,” Supplementa ad Acta Hydrobiologica, Vol. 8, No. 1, 2006, pp. 79-90.

[32] E. P. Odum and G. G. W. Barrett, "Fundamentals of Ecology,” Saunders Company, Philadelphia, 2004.

[33] G. E. Fogg, “Algal Culture and Phytoplankton Ecology,” Wisconsin University Press, Wisconsin, 1975.

[34] R. G. Wetzel, “Limnology,” 3rd Edition, Academic Press, California, 2001. 